This is the Accepted Manuscript of an article published by Taylor\&Francis in Journal of immigrant \& refugee studies on 26 May 2017, available online DOI 10.1080/15562948.2017.1307478

\title{
Migrant domestic workers and human trafficking in Greece: expanding the narrative
}

Situated at the cross-road of three continents, Greece, a major entry point of migration flows into Europe, has remained a prime spot for criminals transporting and exploiting human cargo over at least two decades. The geographical location of the country, its European Union (EU) membership, the frailties in its asylum and migration system as well as difficulties in monitoring the admittedly high numbers of new arrivals have rendered the country particularly attractive to human traffickers. According to the United Nations, Greece ranks "very high" as a destination country and "high" as a transit country (UNODC 2006); while Europol has identified Greece as one of Europe's key trafficking in human beings (THB) hubs (EUROPOL 2011).

In response, over the past 15 years the government has repeatedly revised its anti-trafficking legislation and increasingly invested at the operational level - the emphasis being on detecting the victims and arresting the traffickers (Hellenic Parliament, 2012).

Trafficking in domestic work is notably absent within the official statistics. To this day, only one case has been formally registered by the police. Notably, labour trafficking in general is considered a recent phenomenon (Interview with Anti-Trafficking Unit, May 2015). The very low figures come as a surprise if juxtaposed to the size of Greece's migrant workforce and prevalence in the domestic services sector. It is estimated that one of two migrant women in Greece works in the provision of care and household services; the share of migrants employed as domestic workers is among the highest within the EU. At the same time, informal employment and undeclared work remain widespread, rendering those working in the 
domestic services sector particularly prone to exploitation (Lyberaki 2008; Bellas 2012; Triandafyllidou 2013a).

Exploitation in domestic work was never explicitly excluded from the national strategy. However, it has also not been among the country's key priorities (Interview with National Rapporteur, 2015). THB in domestic work is generally addressed as a form of labour trafficking, without there being an apparent need for adopting programs tailored to the specificities of the domestic services sector.

In recent years, Greece's rather vague policy approach towards THB in domestic work has been complemented by more targeted measures from the field of labour- and migration management. Among the most important initiatives was the 2010 introduction of a mandatory insurance and payment system for domestic workers by means labour stamps ('ergosimo,' Law N.3863/2010). In 2013, an ad hoc regularization scheme sought to legalise the stay of migrant carers for persons with disabilities (Joint Ministerial Decision No 43574/2013). The effect however of these measures in ameliorating abusive working conditions appears limited; informal employment, cash-in-hand wages and undocumented stay remain widespread (Triandafyllidou, 2013a). Furthermore, the impact of these initiatives on protecting potential victims of trafficking lacks official analysis (GRETA 2016)22.

The aim of this article is to analyse Greece's response towards THB in domestic work, through the prism of the relationship between domestic worker and employer. Although the latter has attracted some attention among Greek scholars, mainly from the field of social sciences (Bellas, 2012; Kassimati, 2007; Lyberaki, 2008), its role in Greece's anti-trafficking policy remains in large underexplored. By employing feminist legal theory and specifically relational theories of selfhood and autonomy and relying on empirical findings from the author's field study, the article will advance the following main argument: Greece's labour law fails to 
clearly regulate the relationship between domestic worker and employer, as it falsely assumes that this is naturally a relationship of "trust" and "care". This has placed migrant domestic workers at a social disadvantage, effectively allowing wider discriminatory and oppressive attitudes to flourish; eventually doing little to support the country's antitrafficking policy. Seen through this lens, an effective response to THB in domestic work cannot be confined to better policing activities but requires a more holistic and in-depth restructuring of Greece's regulatory framework on domestic work and an awareness-raising policy, in order to render the protection of potential victims more effective.

In terms of methodology, although the conceptual framework employed originates with legal philosophy, the article is interdisciplinary in nature. It also engages with contributions from the field of social science that focus on the experience of the domestic worker in the Greek society and her relationship to the employer to complement its key findings and discuss the limitations of Greece's anti-trafficking approach. The definition of THB employed in this study may be referred to as the tripartite definition laid down in the 2011/36/EU Directive on preventing and combating THB, looking however at a wider spectrum of severe forms of exploitations that may entail situations of trafficking.

The article will have the following structure. The first part will discuss the empirical findings regarding THB in domestic work in Greece. The very low State figures will be juxtaposed to accounts by governmental and non-governmental sources collected by the author during a 10-month field research in 2015 , which indicate the occurrence of a phenomenon of a much wider scale. The second part will lay down the theoretical framework. Relying primarily on the works of philosophers Nedelsky and Young, this part will develop and define the relational approach as understood from the author's own perspective, namely that of a human rights lawyer. The last part will explore the role of Greek labour law in shaping the relationships 
between domestic worker and employer. It will argue that by leaving these unregulated, oppressive relationships have flourished, embedded within a wider social environment of tolerance and discrimination towards migrant labour that effectively undermine Greece's anti-trafficking policy. The article will conclude with recommendations.

\section{Trafficking in domestic work in Greece: findings from the field}

Human trafficking, including labour trafficking, was first established as a self-standing crime in 2002, following sharp international criticism on Greece's inadequate response towards a growing phenomenon. Since then, Greece's anti-trafficking legislation has undergone a series of revisions in line with international developments. Today, Greece is a party to all major international human rights instruments, including the Palermo Protocols and the Council of Europe Convention on Action against THB (CoE Convention). It has also transposed Directive EC/2011/36. In 2013, Greece appointed its first National Rapporteur on THB (Law N.3064/2002; Presidential Decree 233/2003; Law N. 4251/2014; Law N.4198/2013; Law N.4216/2013)

Official statistics on THB are kept by the Greek police and are based on the annual detections of presumed victims. Incidence data include the number of suspects and victims, the type of exploitation and demographic characteristics such as age, nationality and gender. Additional information may be found in judicial files and the records of public agencies dealing with presumed victims. In the absence of a national database, however, much of the information lies in large fragmented as each State agency keeps its own separate records that are not always digitised. Non-governmental agencies in particular those working on asylum and migration also maintain their own data. 
The article's key findings about the situation on the ground are based on primary data collected by the author during a field study on the demand-side of Greece's anti-trafficking policy in domestic work. Next to desk research, sixteen semi-structured interviews were carried out with key stakeholders active on the field: one public prosecutor, four NGO lawyers, one social worker, three migrants representing migrant associations two of whom were domestic workers, five government officials (one public prosecutor, one police official, one representative of the Ministry of Interior, the National Rapporteur on THB, one representative of the National Centre for Social Solidarity) and two independent experts.

At the beginning of each interview, each stakeholder was asked to provide the working definition of THB in domestic work her organisation uses. Although non-governmental agencies have arguably adopted a broader interpretative approach to the Greek law compared to the more narrow definition used by State authorities (Interview with Public Prosecutor, 2015) these differentiations had little impact on methodological consistency. When asked about known cases of THB in domestic work, hardly any was reported.

According to the official police data and on the basis of the interviews conducted, only one case of THB in domestic work appears to have been formally registered, as late as 2015 . The victim, a woman of third-country origin, had travelled to Greece to work as a domestic worker in a diplomatic household. There she was subjected to harsh working and living conditions, including long working hours, little food and lack of privacy. Eventually she was set free from her employer. The case is currently ongoing.

Another incident, involving a private household, was reported during the interviews by the National Centre for Social Solidarity, a public agency which provides social assistance to suspected victims of trafficking. The events occurred between 2007-2008 and concerned a Balkan woman who had been brought to Greece by a private agent to work as a live-in 
domestic worker. Similar to the previous case, she was subjected to abusive living and working conditions: no privacy, extensive working hours without a schedule, lack of payment. Eventually she escaped.

In the context of Greece, cases of THB that elude the official State statistics often find their way into the asylum system and human rights reports. Surprisingly, this is not the case when it comes to domestic work. Only a handful of situations that bore elements of trafficking in domestic work have been reported throughout the years. They primarily concerned exploitation in middle- and upper-class private households. The lack of adequate data and the great differences in the modus operandi render a trend analysis particularly challenging.

One such case was about an Ethiopian girl who had allegedly been brought to Greece by a Pakistani family to work in their household. She was never paid and was subjected to severe ill-treatment (CCME, 2011). Another case concerned an African girl that had travelled to Greece to work as a hotel-maid, but was forced to work as the hotel-keeper's domestic maid under exploitative terms. She eventually escaped and sought NGO assistance. A third case concerned a Chechen woman who had come to Greece irregularly in the search of work. She was reportedly sedated by some compatriots and transferred to a private house where she was exploited as a domestic worker for five years before being set free (CCME, 2011).

In the course of our interviews, some NGO lawyers described situations that bore elements of transnational re-trafficking. Two cases were reported which concerned a woman of African and Middle Eastern descent respectively. Their accounts were similar: both claimed to have been trafficked for domestic work to a third country prior to their arrival in Greece. After escaping they fled by their own means to Greece and applied for asylum. In both cases the lawyers were convinced about the abuse each woman had suffered but were skeptical about 
the circumstances under which they had arrived to Greece suspecting re-trafficking - whether for domestic service or other purpose.

Interestingly, despite the low number of the cases identified, there was a shared belief among almost all interviewees that trafficking in domestic work might be occurring at a much wider scale than is currently known.

A phenomenon of a more organised nature, corroborating this commonly held suspicion, was described by the two migrant associations we interviewed.

According to the representatives of the Union of African Women in Greece (African women union), women mainly from Ghana, Ethiopia, Uganda, Sierra Leone, South Africa and Kenya have been exploited as domestic workers in Greece over at least three decades. A private agent or an employment agency is normally involved while the travel to Greece takes place through different paths. In the period 2002-2004, for instance, an employment agency in Africa would make all necessary travel and work arrangements and supply the victims with a tourist visa. In recent years, however, the victims travel on their own through the main smuggling paths and are instructed to contact a collaborator in Greece. Very often they also apply for asylum. Most end up working as live-in housemaids in middle-class homes. Exploitation normally consist of hard work and long working hours, without a work schedule or holidays, confiscation of travel documents and in some cases verbal or physical abuse. A common form of deception concerns the salary, as they are often promised the basic salary in Africa. With the currency conversion, this is equivalent to $€ 50$ per month. Many women start planning their escape after getting in touch with other co-nationals and understanding their situation. Very often, however, they end up working in a different house under analogous conditions. Others decide to remain in their situation in the absence of safe alternatives. 
According to the representative of the Filipino migrant association, domestic workers are recruited from Philippines through legal channels, but not as domestic workers; as contract workers or by making use of Law N. 89/1967, which allows offshore companies to hire foreign employees and directors. Most get employed by upper class households. Exploitation normally consists of undeclared work, long working hours and undefined tasks, as the domestic worker is often expected to be on stand-by day and night.

Sporadically, cases of a more organised nature have also been reported by media. One such report, dating 2009, referred to the dismantling of a Moldovan network, that was transferring women from Moldova to work as domestic servants in Greece (CCME, 2011). Another news article, from 2013, described the dismantling of a seven-member criminal gang of Bulgarians that were systematically transferring Bulgarian women into Greece, via the land border, to work as personal caretakers of elderly people. The traffickers were withholding the women's travel documents as well as part of their wages (Ethnos, 2013).

It is noteworthy, however, that despite being perceived as suspected trafficking, eventually almost none of the above-reported cases found its way in the official State records. In the absence also of a judicial decision, Greece's anti-trafficking legislation and policy for domestic workers remains in this sense in large uncharted.

\section{The relational framework of analysing Greece's policy towards trafficking in domestic work}

The marginalisation of domestic work in Greece's anti-trafficking policy stands in stark contrast to the high demand for paid domestic services in the country, provided mainly by migrant women; the ineffective immigration policies designed to address it; and the wider policy debates surrounding migrant labour exploitation. To discuss all these issues, this article suggests a theoretical framework inspired by feminist studies about selfhood, which views 
THB as a criminal offence and human rights abuse embedded in a complex web of oppressive interpersonal relationships (Verhoeven, Gestel, Jong and Kleemans, 2015; Christman, 2014; Meyers, 2014). For the purposes of the present analysis, the focus will be on the relationship between employer and domestic worker.

Contemporary research analysing THB in domestic work in relational terms is relatively scarce. Whilst not necessary based on theories of the self, important contributions stem primarily from the field of social sciences and are often based on empirical research. A major line of inquiry has been the role gender, ethnicity and other demographic characteristics in shaping the relationship between employer and domestic worker, their connection to abuse and the role of State policies in supporting social hierarchies. Among the most influential contributions has been Anderson's account of domestic work as atypical low-wage labour, deeply embedded in complex power relationships, shaped by gender-, race- and class-based divisions. The fact that certain employers prefer to hire migrants as they can exercise greater control over them, highlights in Anderson's view the role of State policies in making some groups vulnerable to exploitation and shaping demand in the context of THB (Anderson 2003; Anderson 2006; Anderson and Davidson 2003). A recent study by Giles et al. explores the experience of migrant domestic workers across different national contexts, with the authors reflecting on the intimate yet often abusive relationship between employer and domestic worker, which renders the regulation of domestic labour and protection from the most severe forms of abuse particularly complex (Giles et al. 2016). It is important to note that most of these studies are not limited to THB, but explore the personal aspects of the relationship between employer and domestic worker along a continuum of abusive behaviours. Nonetheless they provide important insights on the impact of individual behaviour on State policies against severe forms of exploitation, including THB. 
The analytical approach adopted here differs as it primarily relies on legal philosophy to deconstruct the social dynamics of THB in domestic. The starting point is the theoretical approach of philosopher Nedelsky, which will be briefly outlined.

In her seminal work Reconceiving Autonomy back in 1989, legal theorist Nedelsky advanced an alternative account of analyzing policy and law by means of relationships, challenging mainstream approaches towards autonomy and rights. For the purposes of the present analysis the focus will be on her re-conception of rights as relationships and the importance she attached to the role of fostering relationships in the realisation of rights.

According to Nedelsky, the liberal tradition of legal and political thought has been dominated by the idea of the self-made and isolated individual who achieves freedom by erecting walls around himself and the others around him. "The most perfectly autonomous man is the most isolated one."(Nedelsky, 1989). Based on this image, rights are construed as barriers aim to protect the individual from intrusion by his human fellows or the State, so as to ensure individual autonomy and freedom. This assumption, she argued, is however flawed because in reality humans are fundamentally social beings who become the persons they are through a web of relationships, ranging from the most intimate ones, like parents, friends, neighbours to their relation as citizens towards the State and the world (Nedelsky 1989; also Nedelsky, 2011).

Acknowledging that what gives us power is not isolation but our connection to others, necessarily shifts the focus from mainly protecting against others towards structuring relationships of support. Under this alternative framework, rights are no longer conceived as clashes of conflicting interests but as patterns of relationships that can sustain and develop an enriching life. The advantage of adopting such a relational approach and making relationships central to our rights systems, is that we become more aware of the kind of 
values we want to foster and the ways that public structures best protect these (Nedelsky 1989; Nedelsky, 1993; Nedelsky 2011)

In some cases, she argued, it may be the law itself which generates the problem, by structuring oppressive relationships, which may increase a person's vulnerability and obstruct the realization of a right. In other cases, however, it may not be the definition of the law itself but its interpretation and the way it is being enforced which causes the problem. In such cases, it is not the formal rights that need to change but the way in which specific relations systematically re-produce behaviours that are incompatible with the values at stake. The relationships could then be shifted, she argues, through policy interventions of a wider scale that would re-restructure our mutual responsibilities and the ways in which we relate to one another to make rights real (Nedelsky, 2011).

When it comes to normatively defining relationships of support, notions such as care, intimacy, respect and interdependence are recurring themes in her work; which she juxtaposes to feelings of coercion, dependence, passivity and exclusion. Nonetheless Nedelsky does not provide a water-tight definition of what constitutes optimal or oppressive relationships, as their precise normative content appears to vary depending on the context and the values at stake. While a comprehensive review of the normative values of relational accounts would exceed the scope of this article, for the purposes of the present analysis, this article will draw from the influential definition of oppression developed by political philosopher Young (Young, 1990).

According to Young, oppression in its contemporary sense goes beyond the suffering caused by the individual acts of a tyrant and also encompasses the structural limitations and barriers people experience even in a well-intentioned society. Oppression is structural and is 
embedded in the norms, habits and assumptions that underlie society's rules and shape everyday processes.

All oppressed people, she argues, may experience in their everyday lives some constraints in their ability to express their needs, thoughts, feelings and capacities. In that abstract sense, all oppressed people face a similar condition. The contexts however in which people use the term oppression to describe the injustice they suffer may be divided into five main conceptual categories: violence, exploitation, marginalisation, powerlessness and cultural imperialism. This set of distinctions captures in her view in a comprehensive manner all ways in which oppression can be experienced by all groups. They may thus function as criteria to determine whether and the extent to which individuals and groups are oppressed. To establish the presence of oppression it suffices if the experience of one of these five conditions has been established (Young, 1990)

In light of the theoretical framework described above, namely the use of relationships to analyse law and policy and the reliance on Young's set of criteria to determine the presence of an oppressive relationship in this particular context, the rest of this article will deconstruct Greece's anti-trafficking response by focusing on the relationship between domestic worker and employer.

\section{The relationship between employer and domestic worker under Greek labour law}

Under contemporary Greek law, domestic work is broadly defined and encompasses both household chores as well as care services, live-in and live-out work. Domestic work has the status of "dependent employment", but deviates from standard labour law norms along multiple axes (Ministry of Labour, Document No.40578/898/2.1.2014). 
The general principle regulating the terms of employment is that of contractual freedom; employer and domestic worker are prima facie free to negotiate the conditions of work within certain limits (Ministry of Labour, Document No.40578/898/2.1.2014). In delineating these limits the Greek law distinguishes thereby between live-in and live-out domestic workers, granting a much wider scope of contractual freedom to the former. Notably, critical areas that are exempt from standard labour law limitations and can be freely agreed upon between the live-in domestic worker and employer involve fundamental labour rights: upper working time limits, work during Sundays/holidays/ at night, overtime work and minimum wage requirements.

In justifying the non-applicability of the usual labour law rules, the Greek law cites the "special nature of live-in domestic services and the particular circumstances under which they are provided namely inside the domestic environment, under conditions of trust and special care". Greece's labour law model, which leaves domestic work in large unregulated, appears to be built on the assumption that live-in domestic worker and employer are naturally connected through a mutually caring, intimate and trusting relationship. As a way of protecting this special bond, limitations that are otherwise applicable are lifted, so as to allow the relationship between domestic worker and employer to naturally flourish.

Migrant domestic workers are subject to the same provisions as Greek domestic workers but are in addition required to have a valid work and residence permit (Law N. 4251/2014). Nonetheless, Greek courts have persistently ruled that even undocumented domestic workers are entitled to the same (limited) labour rights with those staying in the country legally. It is also noteworthy that, to this day, Greece has not ratified the ILO Domestic Workers Convention. 


\section{The relationship between employer and domestic worker in practice}

The dynamics in the relationship between domestic worker and employer in Greece have evolved as an intersection between gender and migration.

In the early days, paid domestic work was seen as a form of servitude that was naturally reserved to women. Until the mid-20th century, domestic services were provided mostly by single Greek women from poor families who would migrate to the urban centres and work in middle- and upper-class households, in order to collect sufficient dowry that would allow them to get married. Domestic work was thereby viewed less as a formal employment but as a transit phase in a woman's life. Even though the conditions were often exploitative, there was little incentive to lay down basic labour rights; to an extent also because no woman would openly ascribe to a long-term career as a housemaid (Hatzaroula 2009).

Profound social changes during the 80's and 90's and in particular the entry of Greek women into the formal labour market changed significantly the manner in which domestic services were supplied. While care remained the primary responsibility for Greek women, in the absence of adequate welfare structures and as demand for external household assistance outran supply, foreign workers were recruited; in their majority women. This shift arguably contributed to the professionalization of domestic work, but also fuelled the growth of informal employment - often to the detriment of labour rights (Lyberaki 2008 ; Psimmenos and Skamnakis 2008).

The first wave of domestic workers in Greece consisted of young Filipino women, often assigned with child-caring duties because of their Christian background and command of English (Topali 2009). In the 90s, the fall of the Soviet bloc was followed by an influx of middleaged Eastern European women, (Bulgaria, Ukraine, Georgia and Romania), travelling alone, who were mostly employed as live-in caretakers for the incurably sick or the elderly (Kassimati 
2007; Bellas 2012). Albanian domestic workers came to Greece during the same period, with their families, and worked as part-time cleaners for different employers (Kassimati 2007). Today, domestic work is the main informal occupation of migrant women residing in Greece; live-in domestic work, in particular, has been practically abandoned by the Greek workforce (Bellas 2012; Topali 2008).

In their in-depth study on domestic work, Papataxiarchis and Topali (2007) analyse how Greece's flexible labour framework on domestic work has allowed different nationalities to develop different strategies and types of relationships with their employer, according to their own interpretation of domestic work and self-perception. For Greek domestic workers, the relationship is marked by contradicting self-perceptions about the role of the woman in the household. Working on a part-time basis, she is guided by her own imagery of the "employer in need", assumes the role of the householder, perceiving herself as her employer's substitute; while the employer often resorts to a partial physical presence in the house to symbolically illustrate that she is still in charge. Domestic work arrangements with Albanian workers on the other hand, are also part-time and tend to take the form of a clear-cut division of tasks, essentially producing a two-level household. Filipino domestic workers have assumed the live-in services, adopting the role of the compliant servant that acts as the silent extension of the householder; the employer develops a bond of kinship but at the same readily allocates all tasks, while maintaining nominal control.

The insights provided by the interviewees during our research demonstrate how this flexible framework is also capable of tolerating the development of relationships of extreme dependency, abuse and subordination, allowing to the worker little space for selfdetermination; her choices are often limited to merely planning her escape. 
In the context of our field research, the interviewees were asked to describe the key elements which in their view drive and shape demand for the domestic services provided in the context of THB in Greece. In their replies, the interviewees agreed that Greek employers are not necessarily looking for 'trafficked' labour; but for services that migrant workers currently offer in the most cost-efficient and exploitable manner. Financial exploitability, the exertion of power, control and impunity were ranked the highest, followed by social prejudices and stereotypes. Seen together with the experience of abuse and demeaning behaviours that the migration associations shared, the key features of the employment relationships that were described meet in large the five dimensions of oppression proposed by Young.

Almost all interviewees underscored the cheap labour migrant domestic workers offer and their susceptibility to financial exploitation. Not only do migrants settle for less compared to Greek domestic workers but they also offer better value for money. For women from African countries, for instance, remuneration is low, ranging between 50-400 EUR. For Filipinas, the salary is higher but relatively low compared to the amount of work carried out. The work appeared for both categories exhausting: 12-15 working hours per day, no summer holidays or Sundays, absence of a schedule; conditions a Greek domestic worker would not easily agree to. One migrant woman reported that in households with more than one domestic worker, Greeks and migrants are often paid different wages; the Greek worker earns more and leaves after eight hours of work. The recent financial crisis appears to have further exacerbated the working conditions. The Filipino association described that households prefer to hire one worker, instead of two, who will perform all the tasks. Living in the employer's house for many years and presumably forming a familial bond with the employer does not necessarily impede the exploitation. According to the Filipino association, employers 
sometimes even use this bond and mutual trust as an excuse to avoid declaring the migrant's work, which is economically more advantageous for them (Kassimati, 2007).

Notions of control and subordination were also invoked as key elements of the employment relationship. Particular significance was thereby attached to the undocumented status of the migrant, as it is often connected with fewer demands from the side the employees, who are anxious about their stay, making them an attractive workforce. One African woman we interviewed reported how she was living in constant fear when she first arrived in the country, even being scared to step out of the door to sweep the staircase. Kassimati describes that once migrant domestic workers legalise their stay, their behaviour changes and they become more assertive about their rights (Kassimati 2007). The lack of knowledge among migrants about their rights and entitlements appears to act as an additional advantage from the perspective of the employer. The African women union reported that domestic workers often do not know that they are entitled to the same salary as Greeks, that their salary is too low or that they can be insured and that they eventually learn about their rights through their compatriots. The undocumented status also places a migrant domestic worker in a situation of extreme dependence, allowing the Greek employer to impose exploitative working conditions and even become physically and verbally abusive without fear of repercussions. Domestic workers who stand up for their rights or complain are often threatened with eviction; a threat that carries a particular weight for an undocumented migrant, as it means she loses everything, the shelter, the security, her income (Interview with African women union, July 2015).

Social stereotypes and prejudices as well as cultural assumptions about skills and personality, may also shape the expectations and attitude of the employer; even though these lines are not absolute as the migrant domestic worker might be allocated tasks other than those 
initially assigned. In a study in 2008, Psimmenos and Skamnakis reported how discriminatory attitudes and prejudices restricted the job opportunities of certain nationalities to the domestic work sector and shaped work relations of patronage (Psimmenos and Skamnakis 2008). The Filipino association attributed the demand for Filipino domestic workers to their perceived loyalty but also their passive behaviour, which is particularly appreciated in the affluent neighbourhoods where they work (also Topali, 2009). The African women who participated in the interview referred to their perceived ability for hard work; contrary to Greek housemaids, they are considered less demanding and more resilient, ready to do work even if they are sick or menstruate.

If reviewed as a whole, the empirical findings regarding the relationship between domestic worker and employer in Greece collected during our research and documented within Greek literature, allow us to draw the following preliminary conclusions: first, in the absence of more concrete labour regulations on domestic work, diverse types of relationships between employer and domestic worker have been made possible in Greece. While some might meet the ideal of the mutually trusting and caring relationship that Greek law assumes, many others are marked by exploitation, extreme dependency, denigration and even overt violence and abuse. Second, although it is open to debate to what extent the abuses described above were experienced within the narrow context of THB or concerned other forms of exploitation, there is nonetheless an undisputed connection between an oppressive employment relationship and THB in domestic work (Anderson and Davidson, 2003). In the case of Greece, migrants who enter into such an abusive relationship are often deprived of their employment rights, become especially vulnerable to a series of human rights abuses but also lack the necessary support to confront or escape their exploiters. All three situations are directly relevant to the success of Greece's anti-trafficking policies. 


\section{Oppressive employment relationships as a structural phenomenon}

Understanding the full effects of the lack of labour regulations on domestic work and its impact on Greece's anti-trafficking strategy requires looking also into the wider issue of migrant labour exploitation in the country. The limitations of Greece's anti-trafficking framework towards THB in domestic work do not lie in the letter of the law itself. THB for the exploitation of domestic work constitutes a felony which carries a heavy sentence; and the definition of THB adopted in national law is in itself in accord with international human rights standards (GRETA, 2016). The lack of enforcement can be in large traced to deeply embedded public perceptions about migrant labour exploitation. On the one hand, there is a certain bias in THB being primarily connected to prostitution; whereas abuse outside the sex industry is more likely to be perceived as labour exploitation. On the other, as reflected in the perception of several interviewees, the kind of abuse domestic workers face seems less unsettling compared to the severe forms of exploitation documented in other sectors of the Greek economy. The fact that exploitation takes place in the privacy of a home and is therefore less visible or known further strengthens this bias.

Material from scholarly research, international sources, media but also official government documentation concede that a significant segment of Greece's migrant workforce is subject to exploitative working conditions (FRA 2014). The most commonly reported forms of exploitation include undeclared work, absence of a contract, very low wages or no payment at all, exposure to harsh working and living conditions. Agriculture, the food and tourism industry, domestic work and cleaning services are the sectors mostly affected by such practices (FRA, 2014). 
At the scholarly level, the mistreatment of migrant workers by their Greek employers has been causally linked to a migrant's irregular status and consequently explored in light of the country's immigration policies, which are at best described as dysfunctional. Whether by design or coincidence, the legislation and administrative practices that the State has adopted to manage migration into the country, have maintained the size of undocumented migrants consistently high; thereby maintaining and reproducing their exploitability (Lyberaki 2008 ; Bellas 2012; Triandafyllidou 2013b; Cheliotis, 2012). Domestic work forms no exception. The process to legally recruit foreign domestic workers is bureaucratic and arduous, often acting as a deterrent for prospective employers (Maroufof, 2013). Next to the ineffective migration regime, parameters such as the occupational segregation of migrants to low-prestige and lowpaid jobs, xenophobic attitudes and popular anti-migrant political rhetoric have arguably further enabled, if not sustained, discriminatory patterns of apathy and tolerance towards migrant labour exploitation in both society and State (Triandafyllidou 2013b; Cheliotis, 2012). The structural dimension of the exploitation that a domestic worker may experience was in large corroborated by the empirical findings of our research. Many interviewees saw the abuse migrant domestic workers often face by their employers as part of broader discriminatory attitudes towards migrant workers that arguably characterise the Greek society at large. Several interviewees criticised how it has become almost socially acceptable in Greece to hire a migrant domestic worker, not insure her, pay her very little, expect her to work very hard and not inform her about her rights. One State official from the social services sector commented how these discriminatory attitudes are even reflected in the ease, with which Greeks talk about the exploitative working conditions of their domestic workers to their social circles. 
The implications of such a social environment of discrimination and apathy on Greece's antitrafficking policy was illustrated in the case of 'Manolada', which the first case of THB in agriculture to reach the national courts. (Mixed Jury Court of Patra, Decision No $75,76,77,78$ 79-80-81, 85-86-87, 111-112-113-114-115-116-117-118-119-120-121-122-123-124-125-126127-128/2014). The victims, in their majority undocumented migrants, had worked for five months under harsh working and living conditions on a strawberry farm, without receiving the (low) wages they had been promised. When they complained, they were shot at by the farmer's guards. The Greek court, however, acquitted the defendants from the charges of THB. It found that the terms of employment, described by the prosecutor as slavery-like conditions and in breach of Greek labour law, were common in the specific rural region; and the migrants, who had not been in any way physically confined, had freely consented to those terms. In discussing the judgment, one independent expert attributed the difficulty to frame labour exploitation in terms of THB to social perceptions about the presumably less cruel nature of the abuse involved. Compared to the suffering experienced by sex workers, the economic exploitation of domestic workers in particular in light of the financial crisis appears less severe. Other interviewees felt the outcome of Manolada might have been different, had the case been decided by an urban-based court.

\section{Conclusion}

The aim of this article has been to provide new insights to the discourse on THB in domestic work in Greece. By placing the relationship employer and domestic worker at the center of its analysis it inquired into the ways in which individual behaviours in the private sphere may foster or undermine Greece's anti-trafficking policy. Several conclusions were drawn in this analytical process. It was found that in the absence of tighter labour law regulations, different 
kinds of relationships had been made possible, largely shaped by gender-, race- and classbased divisions permeating Greek society. Relying on the author's own empirical research and scholarly analysis this article saw an intrinsic connection between the quality of the employment relationship and the success of a State's anti-trafficking policies in the domestic services sector. This finding carries immense practical implications for both law and policy. In many respects, essential gaps in Greece's anti-trafficking strategy in domestic work, including inadequate victim identification, presumable under-reporting and absence of judicial convictions may be causally linked to oversights in Greece's labour law regime. Compared to other forms of trafficking, that are more public, in the context of domestic work the success of Greece's anti-trafficking policy effectively depends on the victim's initiative to come forward. Given that this will rarely be the case, in particular where trafficker and employer are the same person, the chances of detection become dramatically slim. The relational approach to THB does not only provide the necessary empirical support for complementary strategies to traditional law enforcement interventions, but also highlights the role of the individual in State policies. Targeting the value system of the individual, raising awareness among those that come in direct contact with potential victims and sensitising the public on human suffering ought to form indispensable components of national policies. 


\section{Bibliography}

1. Anderson, B. (2003) Just Another Job? The Commodification of Domestic Labor, in Ehrenreich, B. and Hochschild, A. (eds.), Global Woman: Nannies, Maids and Sex Workers, Granta Books, 104-114

2. Anderson B (2007), A very private business: exploring the demand for migrant domestic workers, European Journal of Women's Studies, Vol 14 Issue 3, pp. 247267

3. Anderson, B, and O'Connell Davidson, $\mathrm{J}$ (2003) Is trafficking in human beings demand driven? A multi country pilot study, IOM Migration Research Series No 15, https://www.compas.ox.ac.uk/media/ER-2004-Trafficking Demand Driven IOM.pdf

4. Bellas, C. (2012) Social Integration of Migrant Domestic Workers and the Greek Economic Crisis, Athens: University of Aegean publ.

5. Cheliotis L. (2016) Punitive Inclusion, The Political Economy of Irregular Migration in the Margins of Europe, European Journal of Criminology, 1-22, http://www.Icheliotis.net/uploads/2/2/0/5/22057848/punitive inclusion the political economy of irregular migration in the margins of europe leonidas cheliotis - final proofs.pdf

6. Christman J. (2014) Coping or Oppression: Autonomy and Adaptation to Circumstance, in Autonomy, Oppression and Gender, (eds) A. Veltman and M. Piper, Oxford: Oxford University Press, pp. 202- 226

7. Constantinou A. (2013) Human Trafficking on Trial: Dissecting the Adjudication of Sex Trafficking Cases in Cyprus, Feminist Legal Studies, 21(2):163-183

8. Ethnos (2013) 'Network trafficking women dismantled', http://www.ethnos.gr/koinonia/arthro/eksarthrothike kykloma emporias gynaikon$63832848 /$

9. Europol (2011) 'Trafficking in Human Beings in the European Union', https://www.europol.europa.eu/content/publication/trafficking-human-beingseuropean-union- 2011-1507

10. FRA (2014) Severe Forms of Labour Exploitation-Greece,

11. GRETA (2016) Government's Reply to GRETA's Questionnaire, GRETA(2016)22, https://rm.coe.int/CoERMPublicCommonSearchServices/DisplayDCTMContent?docu mentld $=09000016806 a 7 f a 1$

12. Hatzaroula, P. (2009) 'A genealogy of the exclusion of paid domestic labour from the

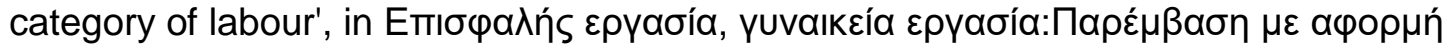

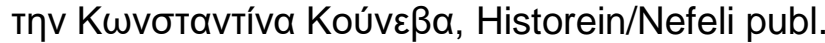

13. Hellenic Parliament (2012) "Transposition to the domestic order of Directive EU/2011/36 - Actions to effectively combat trafficking in human being", http://www.hellenicparliament.gr/UserFiles/67715b2c-ec81-4f0c-ad6a476a34d732bd/7837869.pdf

14. Kassimati, K. (2007) 'Employers of Migrant women domestic workers from Albania and Ukraine', The Greek review of Social research, 124C:95-119

15. Lyberaki, A. (2008) 'Deae ex Machina”: migrant women, care work and women's employment in Greece"' GreeSE Paper No 20, Hellenic Observatory Papers on Greece and Southeast Europe

16. Maroufof, M. (2013) 'With All the Cares in the World': Irregular Migrant Domestic Workers in Greece', Irregular Migrant Domestic Workers in Europe: who cares?, (ed). A. Triandafyllidou, Ashgate publ., 95-114

17. Meyers D.T. (2014) Feminism and Sex Trafficking: Rethinking Some Aspects of Autonomy and Paternalism, Ethical Theory Moral Practice, 17(3): 427-441

18. Nedelsky J. (1989) Reconceiving Autonomy: Sources, Thoughts and Possibilities, Yale Journal of Law and Feminism, 1(1):7-36

19. Nedelsky J. (1993) Reconceiving Rights as Relationship. Jennifer Nedelsky. Review of Constitutional Studies, 1(1): 1-26 
20. Nedelsky J. (2011) Law's relations : a relational theory of self, autonomy, and law, New York:Oxford University Press

21. Papantoniou-Frangouli M., in collaboration with Dourida V., Diamantopoulou A., Barla E. \& Kapsalis A., (2011) "Labour Trafficking in Greece", CCME, http://www.ccme.be/fileadmin/filer/ccme/20 Areas of Work/10 Slavery AntiTrafficking/National reports/2011-03-Greek Report GOING BEYOND.pdf

22. Papataxiarchis, E. \& P. Topali P.(2007) Position Paper from the workshop 'Migrant domestic workers and the construction of households: Comparative perspectives' , https://www.sa.aegean.gr/Synedrio/Synedrio file/Pyth D PositioPaper post.pdf

23. Psimmenos,J. \& C.Skamnakis (2008) Domestic Work and Social Protection, the case of immigrant women from Albania and Ukrania, Athens:Papazisis publ.

24. Giles W., Preston V. and Romero M., (eds), (2016), When Care Work Goes Global: Locating the Social Relations of Domestic Work, Burlington:Ashgate publ. 2016

25. Topali, P. (2008) Worlds of Domestic Work:Gender, Immigration and Cultural Transformations in early 21st century, Athens: Alexandria.

26. Topali, P. (2009) 'Construction of Care in modern Greece: gendered relationships between Filipina domestic workers and Greek employers', Asian Journal of Women's Studies, 15(1):94-124.

27. Triandafyllidou, A.(2013a) Irregular Migrant Domestic Workers in Europe: who cares?, Aldershot:Ashgate publ.

28. Triandafyllidou A, (2013b) "Migration Policy in Southern Europe: Challenges, Constraints and Prospects", LSE, IDEAS project, http://www.Ise.ac.uk/IDEAS/publications/reports/pdf/SR017/Triandafyllidou.pdf

29. UNODC (2006) 'Trafficking in Persons: Global Patterns'. Vienna: United Nations Office on Drugs and Crime (UNODC), http://www.unodc.org/pdf/traffickinginpersons report 2006ver2.pdf

30. Verhoeven M., Gestel B., Jong D. and Kleemans E.(2015), Relationships Between Suspects and Victims of Sex Trafficking. Exploitation of Prostitutes and Domestic Violence Parallels in Dutch Trafficking Cases, European Journal on Criminal Policy and Research, Vol.21(1):49-64

31. Young I.M. (1990) Five Faces of Oppression, Theorising Feminisms, E. Hackett, \& S. Haslanger (Eds.)(3-16) 